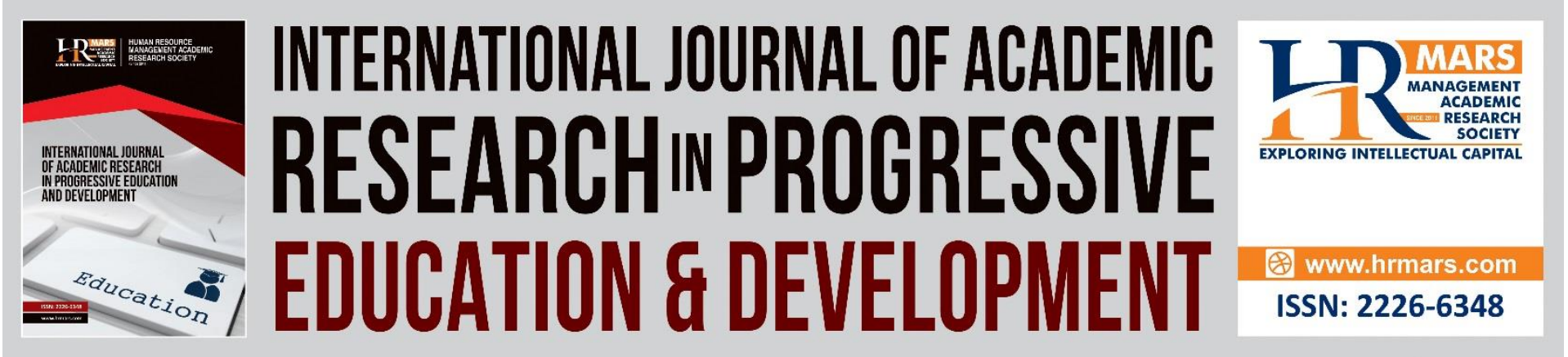

\title{
The Influence of Arabic Lecturers Teaching Strategies on Student Understanding in Universiti Teknologi MARA
}

Nurul Asma Mazlan, Suhaila Zailani @ Ahmad, Zamri Arifin, Nur Aqilah Norwahi, Kaseh Abu Bakar

To Link this Article: http://dx.doi.org/10.6007/IJARPED/v10-i3/10715

DOI:10.6007/IJARPED/v10-i3/10715

Received: 14 June 2021, Revised: 20 July 2021, Accepted: 30 July 2021

Published Online: 05 August 2021

In-Text Citation: (Mazlan et al., 2021)

To Cite this Article: Mazlan, N. A., Ahmad, S. Z. @, Arifin, Z., Norwahi, N. A., \& Bakar, K. A. (2021). The Influence of Arabic Lecturers Teaching Strategies on Student Understanding in Universiti Teknologi MARA.

International Journal of Academic Research in Progressive Education and Development, 10(3), 94-99.

\section{Copyright: (C) 2021 The Author(s)}

Published by Human Resource Management Academic Research Society (www.hrmars.com)

This article is published under the Creative Commons Attribution (CC BY 4.0) license. Anyone may reproduce, distribute, translate and create derivative works of this article (for both commercial and non-commercial purposes), subject to full attribution to the original publication and authors. The full terms of this license may be seen

at: http://creativecommons.org/licences/by/4.0/legalcode

\section{Vol. 10(3) 2021, Pg. 94 - 99}

Full Terms \& Conditions of access and use can be found at http://hrmars.com/index.php/pages/detail/publication-ethics 


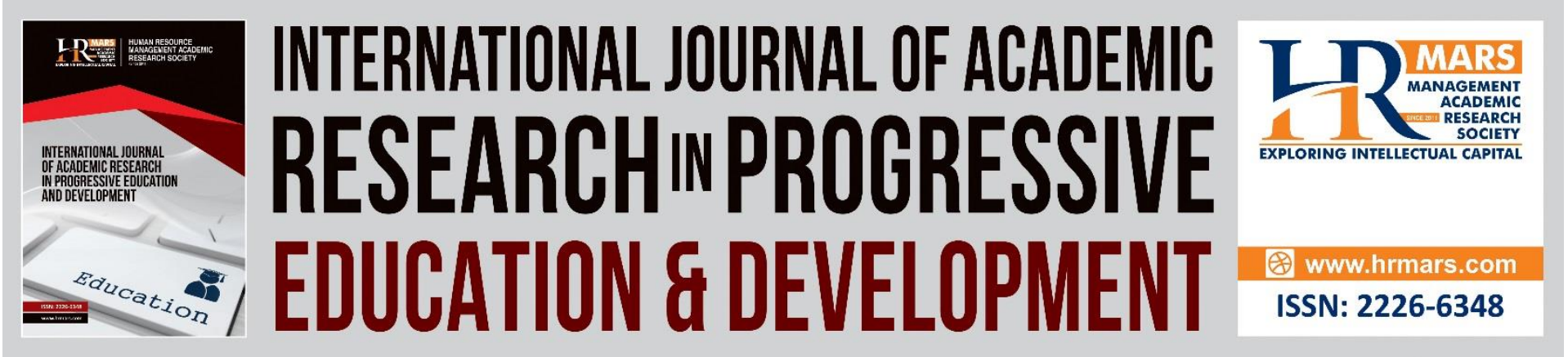

\title{
The Influence of Arabic Lecturers Teaching Strategies on Student Understanding in Universiti Teknologi MARA
}

\author{
Nurul Asma Mazlan \\ Academy of Language Studies, Universiti Teknologi MARA Melaka, Malaysia \\ Suhaila Zailani @ Ahmad, Zamri Arifin \\ Faculty of Islamic Studies, Universiti Kebangsaan Malaysia, Malaysia \\ Nur Aqilah Norwahi \\ Academy of Language Studies, Universiti Teknologi MARA Melaka, Malaysia \\ Kaseh Abu Bakar \\ Faculty of Islamic Studies, Universiti Kebangsaan Malaysia, Malaysia
}

\begin{abstract}
Acquiring a new language is indeed a challenge to students especially if they are required to learn it without any experience in practicing the language. Students understanding in new language acquisition is also depended on the language lecturers' teaching strategies. Hence, the purpose of this study is to explore the effectiveness of Arabic language lecturers' teaching strategies on students understanding in Universiti Teknologi MARA (UiTM). A total of 348 students from various faculties at three different campuses in UiTM South Zone campuses (Negeri Sembilan, Melaka and Johor) were conveniently selected and responded in this study. The statistical Package for Social Science (SPSS) was used to analyse data through descriptive and Partial Least Square Structural Equation Modelling (PLS-SEM) used to analyse data through correlation analysis. Referring to the correlation analysis, the finding is expected to reveal that there is a positive and strong relationship between Arabic language lecturers' teaching strategies and students understanding. It is also expected to reveal the teaching strategies mostly adopted by the Arabic language lecturers in creating an effective and meaningful language learning environment.
\end{abstract}

Keywords: Arabic language Lecturer, Student Understanding, Teaching Strategy, Teaching Technique.

\section{Introduction}

Arabic language has been one of the languages offered as an elective course for over 20 years in Universiti Teknologi MARA (UiTM) and is deemed to be a tough language to acquire 
proficiently. Nevertheless, there are more students that show interest in learning the language and sign up for the course despite the awareness of the difficulty level of acquiring a new language. This is possibly due to more countries now have realised the demand of Arabic language in the international community (Moghazy, 2021). According to Albantani and Madkur (2019), the challenges in learning Arabic language include Arabic language teachers' teaching strategies particularly in the adaptation to technology, students' low motivation to learn, and uncertainty of policies on language teaching. Hence, this study investigates the teaching strategies by Arabic language lecturers and their influence on students' learning outcomes.

\section{Literature Review Teaching Strategies}

According to Brown \& Atkins (1993), the main challenge for a lecturer is to identify the student readiness before a teaching and learning session as it will shape the initial perception of the students towards the lecturer. Medley (2012) stated that the quality of the student and lecturer relationship between plays a role in students' willingness to participate during lectures. He believes that if a positive relationship exists between the lecturer and the student, the student strives and collaborates better with their lecturer, making the lectures to be more impactful. Commonly, for students, the main role of the lecturer is to teach but at the same time expect the lecturers to provide a clear description on any learning challenges and guidance towards solving them.

Hence, lecturers need to adopt effective strategies to improve students' understanding in order for students to acquire Arabic language. In the context of Arabic language classroom, student-centered strategies are more appropriate to university students as they are usually less structured and are able to develop creative and critical thinking skills, as well as encouraging their involvement to understand the learning concepts (Mahmood, 2012). In fact, students would feel more responsible in their own learning process. Yusri et. al (2011) added, student-centered activities in the Arabic language curriculum is the best strategy that should be practiced by all lecturers because the nature of the language itself requires active interaction in order to master it. This is because, as university students, their maturity helps in understanding the concept of teaching and learning and are usually more outspoken when sharing their views compared to high school students.

\section{Teaching Techniques}

Khalid \& Ismail (2018) have outlined seven aspects that require special attention in classroom which include teaching duration, quantity and quality of information presented, relevant teaching activities, level of student participation, accuracy of facts and concepts taught, appropriate content development activities, speech intonation, questioning techniques and the assessment process. These aspects can be fulfilled once lecturers are aware of appropriate methodologies to be used during their teaching session. This view is in line with Wahab's (1998) study on 145 final year trainee teachers in Terengganu to identify the teaching styles of teacher training college lecturers. He found that these lecturers have the skills and abilities to present ideas efficiently, plan lessons well, explain teaching concepts clearly and easily, know the level of understanding of trainee teachers, show examples appropriate to the subject and also teach through vast experience. 
Further supported by other studies, Yaacob et al (2018); dan Martiny et al (2016) reported that the teaching method outlined by the Ministry of Higher Education (MOHE) in 2012 include methodologies that focus more on classroom activities and projects to create a curriculum content that is in line with the students' field of specialization. In addition, Littleword (1981); Richards and Rodges (1991); Renner (1993); Ruyle (1995); Kamarudin (2007) have listed seven attributes of an effective lecture delivery. The attributes are the lecturer-student interaction, two-way communication, responding to inquiries, sharing responsibilities for an active learning session, students' involvement in group activities and discussion, the use of support materials and lastly, students are not required to pen down lecture notes.

Yusri et al (2020) revealed that teaching and learning strategies with the attributes are found to be effective based on their study at UiTM East Coast zone campuses. It also depends on lecturers' creativity in adapting the attributes into their teaching methods. It is also reported that communicational-based activities such as simulation and roleplay are among the most preferred tasks among the lecturers. This has also been acknowledge by language scholars whereby communicational-based activities are more effective and meaningful to students' language learning development as they emphasise on authentic and active language practice by the students. In short, this method is highly beneficial in enhancing students' proficiency in Arabic language.

\section{Methodology}

Research methodology comprised of vital steps to conduct the research and it was significant to discover the most relevant strategies in order to get efficient outcomes to respond to the problem statement of the research (Kothari, 2004). The purpose of this study is to investigate the influence of Arabic lecturers teaching strategies on students understanding in UiTM South zone campuses. The primary data are obtained through questionnaires that have been administered to the degree students from UiTM Negeri Sembilan (Kampus Seremban and Rembau), Melaka (Kampus Jasin and Bandaraya Melaka) and Johor (Kampus Segamat). The survey has been carried out conveniently by using Google Form to acquire the responses from the respondents. The entire population for this study is 10,709 students from six different faculties that in UiTM South Zone campuses which include the Faculty of Business and Management, Faculty of Computer Science and Mathematics, Faculty of Administrative Science and Policy Studies, Faculty of Accountancy and Faculty of Sports Science and Recreations.

The sample size for this study is 119 students which has been identified mainly by referring to the GPower 3.1 software. However, the total respondents in this study were 348 students. A 5-point semantic differential scale was used to represent most suitable answer from the respondents. The description of the semantic differential scale used include, 1Strongly Disagree to 5-Strongly Agree. To test the reliability of the answers of the questionnaires, reliability analysis is used in the study. The reliability analysis has been performed by referring to the rule of thumb made by Perry, Charlotte, Isabella, and Bob (2004). Both independent (Arabic lecturer teaching strategies) and dependent (students understanding) variables have been tested using SPSS 27.0 and Smart PLS 3.3.3. Besides, the descriptive, correlational, and regression analyses also had been conducted by the researchers to obtain the results for this study. 
DEVELOPMENT

Vol. 10, No. 3, 2021, E-ISSN: 2226-6348 ㄷ 2021 HRMARS

\section{Significance of the Study}

The analysis of this study are expected to identify the teaching strategies adopted by Arabic language lecturers as well as the way these methodologies influence student understanding in acquiring the language. Through the findings, this study also aims to provide insights on language learning strategies deemed effective by the stakeholders. The completion of this study can assist Arabic language lecturers to diversify their teaching strategies in order to achieve high level of student understanding. Besides that, it can also prompt the tertiary institutions and curriculum developers to examine a more comprehensive language course that will achieve its main objective which if for students to acquire the language effectively within the designated time frame.

\section{Conclusion}

As one of the most ancient languages in the world, the Arabic language is now widely used and deemed as influential as French and Spanish languages. The development of Arabic language is growing especially in social, economic, business, politics and tourism sectors (Albantani \& Madkur, 2019). Therefore, effective teaching and learning strategies are imperative to create an innovative, creative and competitive Arabic language learning environment.

On the other hand, it is also crucial to examine student understanding level based on the influence of the teaching strategies adopted by the lecturers. In addition, classroom activities have an important role in determining students' acceptance towards Arabic language. Activities that require students to apply the language in authentic situations such as simulations and roleplays allow the students to develop better understanding and higher self-confidence to express themselves in the language. It is indeed a commitment required from both lecturers and students in establishing an effective Arabic language learning.

\section{Acknowledgement}

The authors would like to express special gratitude to Academy of Language Studies, UiTM Melaka and Faculty of Islamic Studies, UKM for giving trust to our team in conducting this study. The authors also would like to express their very great appreciation to anyone who involved directly or indirectly in this study and kept them motivated to complete this study successfully.

\section{Corresponding Author}

Nurul Asma binti Mazlan

Academy of Language Studies, Universiti Teknologi MARA, Melaka, Malaysia

Email: asmamazlan@uitm.edu.my

\section{References}

Albantani, A. M., \& Madkur, A. (2019). Teaching Arabic in the era of Industrial Revolution 4.0 in Indonesia: Challenges and opportunities. ASEAN Journal of Community Engagement, 3(2), 3.

Brown, G., \& Atkins, M. (1993). Effective Teaching in Higher Education. Routledge, London and New York. 
Kamarudin, S. K. (2007). Personaliti dan Intelektual Pensyarah: Persepsi Pelajar Tahun 1 dan Tahun 4 Fakulti Pendidikan, Universiti Teknologi Malaysia. Universiti Teknologi Malaysia: Tesis Sarjana Muda.

Khalid, M. K. A., \& Ismail, N. (2018). Keberkesanan Pengajaran Pensyarah Ekonomi. Gading Journal of The Social Sciences, 22, 156-161.

Kechil, R., Mydin, A. M., Mohammad W. A. W., Libasin, Z. (2017). The Impact of Blended Learning (BL) In Uitm Cawangan Pulau Pinang. International Academic Research Journal of Social Science, 3(1), 239-244.

Kothari, C. R. (2004). Research Methodology: Methods and Techniques. 2nd Ed., New Age International Publishers.

Krejcie, R. V., \& Morgan, D. W. (1970). Determining Sample Size for Research Activities. Educational and Psychological Measurement. 30, 607-610.

Mahmood, N. (2012). Penggunaan Kaedah Pengajaran Bahasa Arab Dalam Kalangan Guru Peringkat Sekolah Rendah: Satu Penilaian. Tesis Ph.D. Fakulti Bahasa dan Linguistik, Kuala Lumpur: Universiti Malaya.

Martiny, I., Yasim, M., Lubis, M. A., Arafat, Z. (2016). The Use of Teaching Aids in the Teaching and Learning of Arabic Language Vocabulory. Creative Education. 7(3): 6. 28 Mac 2016.

Medley, D. M. (2012). Teacher Effectiveness. Encyclopedia of Educational Research. Fifth Edition. New York: The Free Press.

Moghazy, M. (2021). Teaching and Learning Arabic as a Second Language: A Case Study of Dubai. Teaching and Learning, 10(05), 52-61.

Perry, R. H., Charlotte, B., Isabella, M., \& Bob, C. (2004). SPSS Explained.

Renner, P. (1993). The Art of Teaching Adults. Training Associates: Vancouver, British Columbia.

Richards, J., \& Rodges, T. S. (1991). Approaches and Methods in Language Teaching. Edisi ketiga. UK: Cambridge University Press.

Ruyle, K. (1995). Group Training Methods, In The ASTD Technical and Skills Training Handbook. Kelly L (Ed). Mcgraw-Hill: New York.

Wahab, J. A. (1998). Gaya Pengajaran Pensyarah di Sebuah Maktab Perguruan Terpilihh dari Perspektif Guru Pelatih. Master Sains, Universiti Putra Malaysia.

Yaacob, M., Bohari, F. A. M., Bakar, K. A. (2018). Kecekapan Bertutur Bahasa Arab Dan Pendekatan Pengajaran Berpusatkan Pelajar Berserta Elemen Coaching dan Mentoring. Ajtlhe 10(2): 28-44. Fakulti Pengajian Islan, Universiti Kebangsaan Malaysia.

Yusri, G., Rahimi, N., Shah, P. M., Majid, M. A. A., Wah, W. H. (2012). Penggunaan Bahan

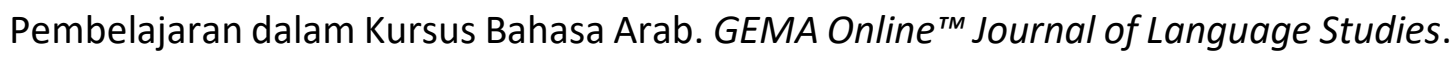
12(1): 215-233.

Yusri, G., Yusoff, M. S. A., Majid, M. A. A., Sahrir, M. S. (2020). Persepsi terhadap pensyarah dan hubungannnya dengan tahap kawalan kepercayaan pembelajaran pelajar bahasa Arab. National Academic Conference 18-19 Jun 2011 bertempat di Renaissance Kota Bharu Hotel, Kelantan. Artikel ini ditambah informasi dan diterbitkan semula pada tahun 2020 dalam http://irep.iium.edu.my/2020/. 